$$
\begin{aligned}
& \text { القاء يلى یلوئيلى در بابونه آلمانى با استفاده از علف كش تريفلورالين }
\end{aligned}
$$

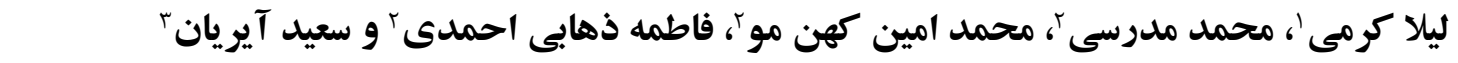

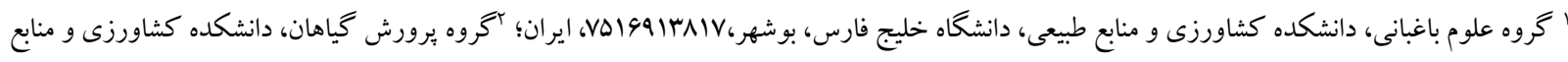

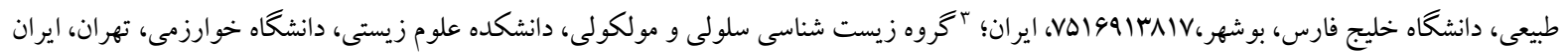

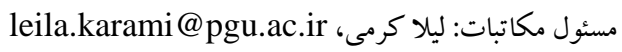

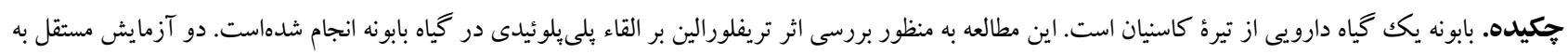

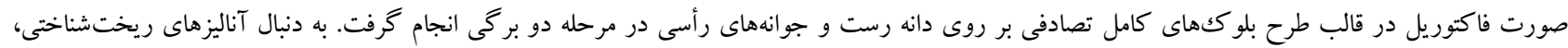

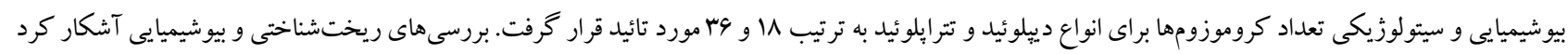

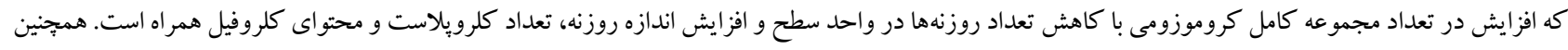

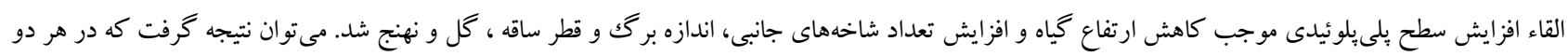

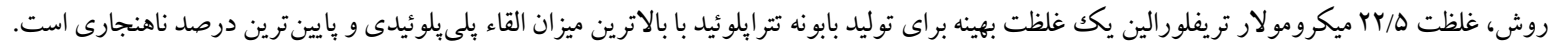$$
\text { وازه هاى كليدى. تغييرات سيتولوزيكى، زمان، صفات ريخت شناسى، غلظت، كروموزوم }
$$

\title{
Polyploidy induction in German chamomile (Matricaria chamomilla L.) by herbicide trifluralin
}

\section{Leila Karami' ${ }^{1}$, Mohammad Modarresi ${ }^{2}$, Mohammad Amin Kohanmoo², Fatemeh Zahabi Ahmadi $^{2}$ \& Saeed Irian ${ }^{3}$ \\ ${ }^{1}$ Department of Horticulture, Faculty of Agriculture and Natural Resources, Persian Gulf University, Bushehr, 7516913817, Iran; ${ }^{2}$ Department of Plant Breeding, Faculty of Agriculture and Natural Resources, Persian Gulf University, Bushehr, 7516913817, Iran; ${ }^{3}$ Department of Cell and Molecular Biology, Faculty of Biological Sciences, Kharazmi University, Tehran, Iran. \\ Correspondent author: Leila Karami, leila.karami@pgu.ac.ir}

\begin{abstract}
Chamomile (Matricaria chamomilla L.) is a medicinal herb belonging to Asteraceae family. This study was conducted to investigate the effect of trifluralin on the induction of polyploidy in chamomile. Two independent full factorial experiments on seedlings and 2-leaf stage apical buds were performed. Following morphological, biochemical and cytogenetic analysis, chromosome numbers of 18 and 36 were detected for diploid and tetraploid types, respectively. Morphological and biochemical examinations revealed that an increase in the number of full chromosome set results in a reduction in stomata number per unit area as well as an increase in stomata size, chloroplast number, and chlorophyll content. Induction of ploidy level increments also reduced plant height and increased the number of lateral branches, leaf size, and diameters of stems, flowers and receptacles. It is concluded that a concentration of $22.5 \mu \mathrm{M}$ trifluralin in both methods is optimum for the production of tetraploid chamomile with the highest rate of polyploidy induction and the lowest percentage of abnormality.
\end{abstract}

Keywords. chromosome, concentration, cytological changes, morphological traits, time 


\section{INTRODUCTION}

German chamomile (Matricaria chamomilla L.) is an annual plant of the Asteraceae family with superficial and cone-shaped root, erect branched stem, 10-80 cm height, and long and narrow leaves (Singh et al., 2011). Chamomile is adapted to a wide range of climatic conditions and grows well at elevations of 300-1500 meters (Singh et al., 2011), and has long been used as a medicinal herb due to its anti-inflammatory, analgesic, antimicrobial and anti-spasmodic effects (Bhaskaran et al., 2010; Tayel \& El-Tras, 2009). In addition, polysaccharides and polyphenolic compounds extracted from German chamomile prevent platelet aggregation and thrombosis (Bijak et al., 2013). The plant is also effective in treating skin disorders, pains, hemorrhoids, ulcers, eczema, sciatica, rheumatic pain, hemorrhoids, mastitis, and chickenpox. Furthermore, this medicinal plant can also be used as tonic or tea to treat anxiety, seizure, nightmares, sleeplessness and other sleep disorders (Srivastava et al., 2010).

Polyploidy refers to changes in the number of chromosome sets. Mutations affecting ploidy level increase the genetic diversity in the plant kingdom and thus are of special importance in natural evolution, plant eugenics and cultivar development. Polyploidy induction can change plant traits through changes in the chromosomal sets, translating into changes in the number of genes and ultimately leading to desirable or undesirable outcomes (Wendel, 2015). In addition to being a natural phenomenon, polyploidy may occur by environmental shocks or use of chemicals such as colchicine and trifluralin, which prevent proper chromosome segregation by depolymerizing microtubules. Nowadays, induction of polyploidy using chemical mutagens is used as a method in plant breeding to increase productivity and/or quality (Das, 2014).

Early experiments using colchicine in breeding programs in chamomile was conducted in the 1950s. Bedegol was the first tetraploid $(4 x=36)$ cultivar of chamomile, developed in Germany. Following this achievement in Germany, other researchers in various countries such as Slovakia ('Goral' and 'Lutea' in 1995), Poland ('Zloty Lan' in 1972 \& 'Dukar' in 2006), Romania ('Flora' \& 'Margaritar') and Bulgaria ('Lazur' in 1980) also developed tetraploid cultivars. It is notable that $25 \%$ of the cultivated chamomile varieties worldwide are colchicineinduced tetraploids (Das, 2014; Sattler et al., 2016).

Trifluralin $\left(\mathrm{C}_{13} \mathrm{H}_{16} \mathrm{~F}_{3} \mathrm{~N}_{3} \mathrm{O}_{4}\right)$, like other anti-mitotic agents such as colchicine, induces polyploidy in plants by inhibiting microtubule polymerization. This chemical compound has also been used in cytological studies (da Silva et al., 2017). In general, the effectiveness and success of polyploidy induction experiments have been low due to its limitations including its ineffectiveness in polyploidy induction when used at low concentrations, induction of plant death when used at high concentrations, undesirable chromosomal changes and production of chimeric plants and plants lacking roots and seeds (Salma et al., 2017). However, it has been reported that trifluralin has better affinity for binding to plant microtubules and its performance is very variable in plant polyploidy induction (Bartels et al., 1973; Zlesak, et al., 2005). Also, trifluralin is cheaper, less toxic and safer compared with colchicine, thus, it can be a suitable agent for chromosomal changes and polyploidy induction (Klima et al., 2008).

Considering chamomile as one of the most ancient medicinal herbs known to mankind and its widespread cultivation by various communities, we set out to investigate the effectiveness of trifluralin as a polyploidy inducer in this plant.

\section{MATERIALS AND METHODS}

This research was carried out in the greenhouse and the genetics laboratory of the Agriculture and Natural Resources Faculty of the Persian Gulf University (Bushehr, Iran) during 2015-2016. Two varieties of chamomile seeds, a native cultivar of Bushehr Province called Dehroud-e-Dashtestan (DD) (prepared from the Center for Genetic Reserves of the Agriculture and Natural Resources Faculty of the Persian Gulf University) and an international cultivar called Buna (Originated from Hungary and provided by the Agricultural Research Center of Isfahan Province) were used. A voucher specimen from each variety was deposited in Herbarium of Agriculture and Natural Resources Faculty of the Persian Gulf University (Bushehr, Iran). Trifluralin solution (EC 48\%, AGROXIR) was used to induce polyploidy.

Two independent full factorial experiments on seedlings and 2-leaf stage plantlets, each with three replicates, were conducted. Cultivar type, trifluralin concentration and application duration were the factors investigated to study the effect of trifluralin on certain morphological, biochemical and cytogenetic characteristics. The traits examined included the number of lateral branches, plant height, stem diameter, leaf length, width and thickness, number of flowers, flower and receptacle diameter, chlorophyll content, stomatal properties, pollen grains, and cytogenetic changes.

For seedling treatment, the chamomile seeds were transferred to petri dishes with filter papers. Following the addition of water, these plates were 
placed in an incubator with a 16-hour light period at 23-24 ${ }^{\circ} \mathrm{C}$ and a 50-60\% humidity to obtain root apical meristem. After three days, germinated seeds with a 1.5-2 cm root length were treated with solutions containing $0\left(\mathrm{H}_{2} \mathrm{O}\right.$ only), 7.5, 15 and 22.5 $\mu \mathrm{M}$ concentrations of trifluralin for 12 and 24-hour periods.

Dropping method using the above-mentioned concentrations of trifluralin was used to investigate the herbicide effect on the plantlets at 2-leaf stage. Seeds of the two chamomile cultivars were cultivated in coco peat trays, with a single seed per well of the tray. Trays were stored in a greenhouse condition with average temperatures of $24{ }^{\circ} \mathrm{C} / 18^{\circ} \mathrm{C}$ in a day/night cycle and a relative humidity of $40 \%$ (Hoseini et al., 2012). A droplet $(\sim 5 \mu \mathrm{L})$ of the trifluralin solution was then applied to apical buds of the 2-leaf stage plantlets once a day for a period of 2 or 3 days.

To determine changes in the ploidy level caused by trifluralin treatment, treated plants were initially inspected for any morphological changes in comparison with the control samples. Next, plants were subjected to light microscopic examination for changes in the characters including stomatal size and density, chloroplast number in stomatal guard cells, chlorophyll content (See equations below) and pollen grain diameter. Finally, to ensure trifluralininduced changes in ploidy level, cells in the root apical meristem of plants obtained following seed treatment were examined cytogenetically by direct chromosome counting. At first, root tips were pretreated by $0.05 \%(\mathrm{w} / \mathrm{v})$ colchicine solution for 4 hours at $4^{\circ} \mathrm{C}$ in order to block the cell cycle at the mitotic metaphase stage. After washing the samples by distilled water for $15 \mathrm{~min}$, meristems were removed and quickly blot-dried the excess water, then fixed in cold Carnoy's solution I (a mixture of 1 part glacial acetic acid and 3 parts absolute ethanol) for $24 \mathrm{~h}$ at $4^{\circ} \mathrm{C}$. Then, they were washed by running water for 3 hours. Root tips were first hydrolyzed in $1 \mathrm{~N} \mathrm{HCL}$ at $60^{\circ} \mathrm{C}$ for $15 \mathrm{~min}$ and washed in distilled water. Meristems were stained by acetocarmine for 2-4 hours at $4^{\circ} \mathrm{C}$ and then squashed on a clean slide in $45 \%$ acetic acid. Slides of samples were analyzed under a 100X objective of a light microscope (Olympus), and the chromosomes were counted in metaphase of mitosis in 5 cells from each root tip.

$$
\begin{aligned}
& \text { Chlorophyll } a=\frac{\left(19.3 \times A_{663}-0.86 \times A_{645}\right) V}{100 \mathrm{~W}} \\
& \text { Chlorophyll } b=\frac{\left(19.3 \times A_{645}-3.6 \times A_{663}\right) \mathrm{V}}{100 \mathrm{~W}}
\end{aligned}
$$

V: Supernatant Volume

A: Absorbance at various wave lengths $(645,663)$

\section{Statistical analysis}

Data were subjected to analysis of variance (ANOVA), and means were compared using Duncan's new multiple range test.

\section{RESULTS \\ Morphological changes}

The results from the ANOVA indicated that all the examined traits in trifluralin-treated seedlings including lateral branching, leaf size (length, width and thickness), stem diameter, flower number and receptacle diameter were affected $(\mathrm{p}<0.01)$ by both concentration and duration of the treatment (Table 1). However, in the 2-leaf stage apical bud-treated plants, these variables were only affected $(p<0.01)$ by trifluralin concentration (Table 2 ). With respect to the cultivars used in these experiments, trifluralin treatment of the seedlings resulted in a significantly greater number of lateral branches, leaf length and thickness, and flower diameter in DD cultivar compared with Bona.

Finally, in the apical bud treated plants, the 22.5 $\mu \mathrm{M}$ trifluralin treatment caused the greatest increase in the number of lateral branches, stem diameter, length, width and thickness of leaves, diameter of flower and receptacle in comparison with the control plants, although plant height and number of flowers in the control samples were higher than the treated plants. It should also be noted that all changes were significantly dependent on trifluralin concentration.

The effect of trifluralin concentration and application time on seedlings were also investigated and the results are reported in Table $3(\mathrm{P}<0.05)$, with different letters in each row of the table indicating the significant differences.

\section{Stomatal properties}

Results of ANOVA (Table 4) indicated that all the examined stomatal properties (ie., chloroplast number in guard cells, stomatal density, length and width) were affected by trifluralin treatment of seedlings based on simple effects and double interaction of factors $(\mathrm{p}<0.01)$. However, these variables were only affected by trifluralin concentration in the apical bud application.

Changes in the stomatal properties following trifluralin treatment of 2-leaf stage apical budding included a significant increase in stomatal width, length and number, while stomatal density in the control group was significantly higher than that in the treated samples (Fig. 1 A-D). It should be noted that these changes were trifluralin concentrationdependent. Finally, following the apical bud treatment with various concentrations of trifluralin in the DD cultivar, stomatal width increased in a concentration-dependent manner, although stomatal density declined. 
Table. 1. Changes in different traits of chamomile grown from trifluralin-treated seedlings

\begin{tabular}{|c|c|c|c|c|c|c|c|c|c|c|}
\hline \multirow{2}{*}{$S V$} & \multirow{2}{*}{$d f$} & \multicolumn{9}{|c|}{ Variables } \\
\hline & & $\mathrm{H}$ & $\mathrm{Lb}$ & $\mathrm{Ll}$ & Lw & $\mathrm{Lt}$ & $\mathrm{Sd}$ & Fn & $\mathrm{Fd}$ & $\mathrm{Rd}$ \\
\hline Repeat & 2 & $231.71^{*}$ & $0.08^{\mathrm{ns}}$ & $1.87^{*}$ & $4.26^{* *}$ & $0.005^{*}$ & $0.10^{*}$ & $0.15^{\mathrm{ns}}$ & $0.10^{\mathrm{ns}}$ & $0.002^{\mathrm{ns}}$ \\
\hline Cultivar & 1 & $577.06^{* *}$ & $0.75^{\mathrm{ns}}$ & $2.39^{*}$ & $0.42^{\text {ns }}$ & $0.01^{*}$ & $0.10^{\mathrm{ns}}$ & $0.19^{\text {ns }}$ & $3.05^{*}$ & $0.003^{\mathrm{ns}}$ \\
\hline $\begin{array}{c}\text { Concentrati } \\
\text { on }\end{array}$ & 3 & $\begin{array}{c}15344.41^{*} \\
*\end{array}$ & $54.14^{* *}$ & $459.82^{* *}$ & $298.58^{* *}$ & $0.29^{* *}$ & $5.13^{* *}$ & $66.52^{* *}$ & $233.95^{* *}$ & $6.29^{* *}$ \\
\hline Time & 1 & $\underset{*}{28100.56^{*}}$ & $90.75^{* *}$ & $837.51^{* *}$ & $453.26^{* *}$ & $0.51^{* *}$ & $9.43^{* *}$ & $31.69^{* *}$ & $328.13^{* *}$ & $2.80^{* *}$ \\
\hline Cul $\times$ Con & 3 & $58.78^{\mathrm{ns}}$ & $0.14^{\mathrm{ns}}$ & $1.38^{\mathrm{ns}}$ & $0.43^{\text {ns }}$ & $0.0004^{\mathrm{ns}}$ & $0.03^{\mathrm{ns}}$ & $0.24^{\mathrm{ns}}$ & $0.31^{\mathrm{ns}}$ & $0.003^{\mathrm{ns}}$ \\
\hline$C u l \times T$ & 1 & $17.27^{\mathrm{ns}}$ & $0.08^{\mathrm{ns}}$ & $0.20^{\mathrm{ns}}$ & $0.39^{\mathrm{ns}}$ & $0.002^{\mathrm{ns}}$ & $0.04^{\mathrm{ns}}$ & $0.19^{\mathrm{ns}}$ & $0.20^{\mathrm{ns}}$ & $0.003^{\text {ns }}$ \\
\hline Con $\times T$ & 3 & $1100.12^{* *}$ & $5.03^{* *}$ & $30.82^{* *}$ & $5.65^{* *}$ & $0.001^{\mathrm{ns}}$ & $0.69^{* *}$ & $1.97^{*}$ & $2.09^{*}$ & $0.20^{* *}$ \\
\hline $\begin{array}{c}C u l \times \operatorname{Con} \times \\
T\end{array}$ & 3 & $10.44^{\mathrm{ns}}$ & $0.14^{\mathrm{ns}}$ & $0.58^{\text {ns }}$ & $0.13^{\text {ns }}$ & $0.0006^{\mathrm{ns}}$ & $0.04^{\mathrm{ns}}$ & $0.24^{\mathrm{ns}}$ & $0.69^{\mathrm{ns}}$ & $0.0005^{\mathrm{ns}}$ \\
\hline Error & 30 & 44.57 & 0.39 & 0.47 & 0.53 & 0.001 & 0.03 & 0.59 & 0.60 & 0.008 \\
\hline$C V$ & & 2.79 & 7.35 & 2.04 & 3.30 & 4.23 & 7.09 & 10.45 & 3.20 & 1.11 \\
\hline
\end{tabular}

Ns: Not significant

*: Significance level 5\%

**: Significance level $1 \%$

Cul: Cultivar; Con: Concentration; T: Time

SV: Source of variation; df, Degree of freedom; H: Height; Lb: Lateral branch; Ll: Leaf length; Lw: Leaf width; Lt: Leaf thickness; Sd: Stem diameter; Fn: Flower number; Fd: Flower diameter; Rd: Receptacle diameter

Table 2. Changes in different traits of chamomile grown from trifluralin-treated 2-leaf stage apical buds plants

\begin{tabular}{|c|c|c|c|c|c|c|c|c|c|c|}
\hline \multirow[t]{2}{*}{$S V$} & \multirow[t]{2}{*}{$d f$} & \multicolumn{9}{|c|}{ Variables } \\
\hline & & $\mathrm{H}$ & $\mathrm{Lb}$ & $\mathrm{Ll}$ & Lw & $\mathrm{Lt}$ & $\mathrm{Sd}$ & Fn & $\mathrm{Fd}$ & $\mathrm{Rd}$ \\
\hline Repeat & 2 & $77.45^{\mathrm{ns}}$ & $0.25^{\mathrm{ns}}$ & $0.42^{\text {ns }}$ & $0.47^{\mathrm{ns}}$ & $0.001^{\mathrm{ns}}$ & $0.01^{\mathrm{ns}}$ & $0.90^{*}$ & $0.13^{\text {ns }}$ & $0.0002^{\mathrm{ns}}$ \\
\hline Cultivar & 1 & $37.12^{\mathrm{ns}}$ & $1.02^{*}$ & $0.63^{\text {ns }}$ & $0.56^{\mathrm{ns}}$ & $0.002^{\mathrm{ns}}$ & $0.001^{\mathrm{ns}}$ & $0.52^{\mathrm{ns}}$ & $0.03^{\text {ns }}$ & $0.005^{\mathrm{ns}}$ \\
\hline $\begin{array}{c}\text { Concentra } \\
\text { tion }\end{array}$ & 3 & $25283.23^{*}$ & $89.08^{* * *}$ & $757.57^{* *}$ & $\underset{*}{453.87^{*}}$ & $0.65^{* *}$ & $4.83^{\text {** }}$ & $40.13^{* *}$ & $299.53^{* *}$ & $7.70^{* *}$ \\
\hline Time & 1 & $753.75^{\mathrm{ns}}$ & $0.52^{\mathrm{ns}}$ & $0.20^{\mathrm{ns}}$ & $0.91^{\mathrm{ns}}$ & $0.0002^{\mathrm{ns}}$ & $0.003^{\mathrm{ns}}$ & $0.02^{\mathrm{ns}}$ & $0.10^{\mathrm{ns}}$ & $0.001^{\mathrm{ns}}$ \\
\hline Cul $\times$ Con & 3 & $18.07^{\mathrm{ns}}$ & $0.24^{\mathrm{ns}}$ & $0.83^{\text {ns }}$ & $0.20^{\mathrm{ns}}$ & $0.004^{\mathrm{ns}}$ & $0.03^{\text {ns }}$ & $0.024^{\mathrm{ns}}$ & $0.22^{\mathrm{ns}}$ & $0.003^{\mathrm{ns}}$ \\
\hline$C u l \times T$ & 1 & $70.06^{\mathrm{ns}}$ & $0.02^{\mathrm{ns}}$ & $1.24^{\mathrm{ns}}$ & $0.01^{\mathrm{ns}}$ & $0.002^{\mathrm{ns}}$ & $0.003^{\mathrm{ns}}$ & $0.52^{\mathrm{ns}}$ & $0.001^{\mathrm{ns}}$ & $0.0002^{\mathrm{ns}}$ \\
\hline Con $\times T$ & 3 & $693.01^{\mathrm{ns}}$ & $0.08^{\mathrm{ns}}$ & $0.20^{\mathrm{ns}}$ & $0.53^{\mathrm{ns}}$ & $0.002^{\mathrm{ns}}$ & $0.001^{\mathrm{ns}}$ & $0.19^{\mathrm{ns}}$ & $0.10^{\mathrm{ns}}$ & $0.002^{\mathrm{ns}}$ \\
\hline $\begin{array}{c}\text { Cul } \times \text { Con } \\
\times T\end{array}$ & 3 & $36.86^{\mathrm{ns}}$ & $0.13^{\mathrm{ns}}$ & $0.24^{\mathrm{ns}}$ & $0.27^{\mathrm{ns}}$ & $0.004^{\mathrm{ns}}$ & $0.001^{\mathrm{ns}}$ & $0.47^{\mathrm{ns}}$ & $0.01^{\mathrm{ns}}$ & $0.0007^{\mathrm{ns}}$ \\
\hline Error & $\begin{array}{l}3 \\
0\end{array}$ & 482.47 & 0.14 & 1.18 & 1.05 & 0.002 & 0.01 & 0.25 & 0.11 & 0.002 \\
\hline$C V$ & & 8.76 & 3.75 & 2.96 & 4.22 & 5.41 & 4.63 & 6.59 & 1.45 & 0.64 \\
\hline
\end{tabular}

Ns: Not significant

*: Significance level 5\%

**: Significance level $1 \%$

Cul: Cultivar; Con: Concentration; T: Time

SV: Source of variation; df, Degree of freedom; H: Height; Lb: Lateral branch; Ll: Leaf length; Lw: Leaf width; Lt: Leaf thickness; Sd: Stem diameter; Fn: Flower number; Fd: Flower diameter; Rd: Receptacle diameter

\section{Pollen grains}

As shown in Fig. $1 \mathrm{E}$ and $\mathrm{F}$, light microscopic examination of the mature pollen grain revealed larger pollen grains in tetraploid plants compared with the control plants.

\section{Biochemical analysis: Chlorophyll content}

ANOVA results on seedling treatment for chlorophyll a, b, and total chlorophyll content revealed a trifluralin effect at the three levels of concentration, duration of application and concentration $\times$ time interaction $(\mathrm{p}<0.01)$. Cultivar effect was also significant for chlorophyll $b$ $(\mathrm{P}<0.05)$. Meanwhile, for apical bud treatment, concentration effect for chlorophyll $\mathrm{a}, \mathrm{b}$ and total chlorophyll content and cultivar effect for chlorophyll $\mathrm{b}$ and total chlorophyll content were significant $(\mathrm{P}<0.01)$. 
Table. 3. The effect of trifluralin concentration and application time on chamomile seedlings

\begin{tabular}{|c|c|c|c|c|c|c|c|c|c|}
\hline \multirow{2}{*}{\multicolumn{2}{|c|}{$\begin{array}{c}\text { Time (hour) } \\
\text { Concentration }(\mu \mathrm{M}) \\
\end{array}$}} & \multicolumn{4}{|c|}{12} & \multicolumn{4}{|c|}{24} \\
\hline & & 0 & 7.5 & 15 & 22.5 & 0 & 7.5 & 15 & 22.5 \\
\hline \multirow[t]{9}{*}{ Trait } & Height & $296.74^{\mathrm{a}}$ & $269.48^{b}$ & $255.33^{c}$ & $233.02^{\mathrm{d}}$ & $276.25^{b}$ & $217.85^{\mathrm{e}}$ & $196.40^{\mathrm{f}}$ & $170.50^{\mathrm{g}}$ \\
\hline & Lateral branch & $5.50^{\mathrm{e}}$ & $6.83^{\mathrm{d}}$ & $6.50^{\mathrm{d}}$ & $9.83^{\mathrm{c}}$ & $6.67^{\mathrm{d}}$ & $9.50^{c}$ & $10.83^{b}$ & $12.67^{\mathrm{a}}$ \\
\hline & Leaf length & $23.38^{\mathrm{g}}$ & $27.57^{\mathrm{f}}$ & $30.15^{\mathrm{e}}$ & $35.95^{\mathrm{d}}$ & $27.27^{\mathrm{f}}$ & $37.92^{\mathrm{c}}$ & $41.12^{\mathrm{b}}$ & $44.17^{\mathrm{a}}$ \\
\hline & Leaf width & $13.65^{\mathrm{g}}$ & $17.67^{\mathrm{f}}$ & $19.95^{\mathrm{e}}$ & $24.33^{\mathrm{d}}$ & $18.00^{\mathrm{f}}$ & $23.68^{\mathrm{c}}$ & $27.58^{\mathrm{b}}$ & $30.92^{\mathrm{a}}$ \\
\hline & Leaf thickness & - & - & - & - & - & - & - & - \\
\hline & Stem diameter & $1.32^{\mathrm{f}}$ & $1.64^{\mathrm{e}}$ & $2.08^{\mathrm{d}}$ & $2.24^{\mathrm{cd}}$ & $1.69^{\mathrm{e}}$ & $2.28^{\mathrm{c}}$ & $3.18^{b}$ & $3.68^{\mathrm{a}}$ \\
\hline & Flower number & $12^{\mathrm{a}}$ & $8^{c}$ & $7^{\mathrm{d}}$ & $5.67^{\mathrm{e}}$ & $9.17^{\mathrm{b}}$ & $6.83^{\mathrm{d}}$ & $5.67^{\mathrm{e}}$ & $4.50^{\mathrm{f}}$ \\
\hline & Flower diameter & $16.17^{\mathrm{f}}$ & $20.35^{\mathrm{e}}$ & $23.47^{\mathrm{d}}$ & $26.10^{\mathrm{c}}$ & $20.67^{\mathrm{e}}$ & $26.58^{c}$ & $28.05^{\mathrm{b}}$ & $31.70^{\mathrm{a}}$ \\
\hline & $\begin{array}{c}\text { Receptacle } \\
\text { diameter }\end{array}$ & $7.27^{\mathrm{g}}$ & $7.38^{\mathrm{fg}}$ & $8.17^{\mathrm{d}}$ & $8.52^{\mathrm{c}}$ & $7.43^{\mathrm{f}}$ & $7.83^{\mathrm{e}}$ & $8.68^{b}$ & $9.32^{\mathrm{a}}$ \\
\hline
\end{tabular}

Significant level: 5\%

Different letters indicate the significant difference

Table. 4. Effect of application time and concentration of trifluralin on chamomile seedlings on stomatal properties

\begin{tabular}{|c|c|c|c|c|c|c|c|c|c|}
\hline \multirow{2}{*}{\multicolumn{2}{|c|}{$\begin{array}{c}\text { TIME (HOUR) } \\
\text { CONCENTRATION }(\mu \mathrm{M})\end{array}$}} & \multicolumn{4}{|c|}{12} & \multicolumn{4}{|c|}{24} \\
\hline & & 0 & 7.5 & 15 & 22.5 & 0 & 7.5 & 15 & 22.5 \\
\hline \multirow{4}{*}{ VARIABLES } & Chloroplast number & $9.83^{\mathrm{e}}$ & $12.00^{\mathrm{d}}$ & $14.17^{\mathrm{c}}$ & $14.83^{\mathrm{c}}$ & $10.17^{\mathrm{e}}$ & $14.67^{\mathrm{c}}$ & $14.67^{\mathrm{b}}$ & $18.50^{\mathrm{a}}$ \\
\hline & Stomatal density & $48.50^{\mathrm{a}}$ & $45.67^{\mathrm{b}}$ & $36.50^{\mathrm{c}}$ & $33.67^{\mathrm{d}}$ & $48.67^{a}$ & $32.67^{\mathrm{e}}$ & $27.83^{\mathrm{f}}$ & $22.67^{\mathrm{g}}$ \\
\hline & Stomatal length & $21.67^{\mathrm{f}}$ & $24.17^{\mathrm{e}}$ & $26.67^{d}$ & $32.00^{\mathrm{c}}$ & $22.92^{\mathrm{ef}}$ & $33.50^{c}$ & $36.67^{b}$ & $45.42^{\mathrm{a}}$ \\
\hline & Stomatal width & $15.42^{\mathrm{f}}$ & $17.92^{\mathrm{e}}$ & $20.00^{\mathrm{d}}$ & $22.92^{\mathrm{c}}$ & $17.08^{\mathrm{e}}$ & $23.33^{c}$ & $25.00^{\mathrm{b}}$ & $27.50^{\mathrm{a}}$ \\
\hline
\end{tabular}

Significant level: $1 \%$

Different letters indicate the significant difference

The highest and the lowest levels of chlorophyll a, $\mathrm{b}$ and total chlorophyll content of seedlings $(\mathrm{P}<0.05)$ belonged to the $22.5 \mu \mathrm{M}$ trifluralin treated and control samples after 24 hours: Chl a (17.23/10.45 mg. $\left.\mathrm{g}^{-1}\right)$, chl b $\left(4.72 / 2.10 \quad \mathrm{mg} \cdot \mathrm{g}^{-1}\right)$, total chl $\left(21.95 / 12.55 \mathrm{mg}^{-1} \mathrm{~g}^{-1}\right)$. The cultivar typexapplication time and cultivar typexapplication timexapplied concentration interactions did not have any significant effect on chlorophyll content. None of the double and triple interactions had any significant effect on chlorophyll content in apical bud experiments, although the b-chlorophyll content of both cultivars increased at higher concentrations of trifluralin for both application methods (Table 5).

\section{Cytogenetic changes}

Root apical meristematic cells of the treated and control chamomile were examined for potential chromosomal changes. Our observations indicated that the chromosome number in somatic cells of both genotypes were 18 and 36 in diploid and tetraploid chamomile, respectively (Fig. 1 G-H).

\section{DISCUSSION}

Quantitative and qualitative traits may change as a result of an increase in the number of gene copies in polyploid plants. The tetraploid chamomile has higher values with respect to various biochemical and morphological traits such as essential oils, bisaboloids, chamazulene, apigenin and flavonoids, as well as height, capitulum size and weight and dry seed weight compared with the diploids (Das 2014, Sattler et al. 2016).

In the present study trifluralin-treated Matricaria chamomilla L. showed an inverse relationship between height and ploidy level, and this decrease in plant height was dependent on both the concentration and duration of application of the herbicide. Amiri et al. (2010) reported that as trifluralin concentration increases, plant height decreases in datura plants (Datura stramonium L.).

Previous studies on tetraploid varieties of feverfew (Tanacetum parthenium L.) (Saharkhiz, 2007), caraway (Carum Carvi L.) (Dijkstra \& Speckmann, 1980) and rosy periwinkle (Catharanthus roseus (L.) G.Don) (Hoseini et al., 2012) have shown a reduction in growth rate in the early stages of growth along with a reduction in plant height during the flowering stage as compared with their diploid counterparts. Indeed, a common outcome of polyploidy in plants is a reduction in the number of cell divisions in the early stages of growth (te Beest et al., 2012). Despite a reduction in plant height due to an increase in ploidy level, the number of lateral branches increased in the tetraploid variety. Such morphological changes have also been reported in polyploid varieties of Colophospermum mopane (Kirk ex Benth.) Kirk ex J.Léonard, Datura stramonium and basil (Ocimum basilicum L.) (Rubuluza et al., 2007; Amiri et al., 2010; Omidbaigi et al., 2012). Therefore, it appears that 

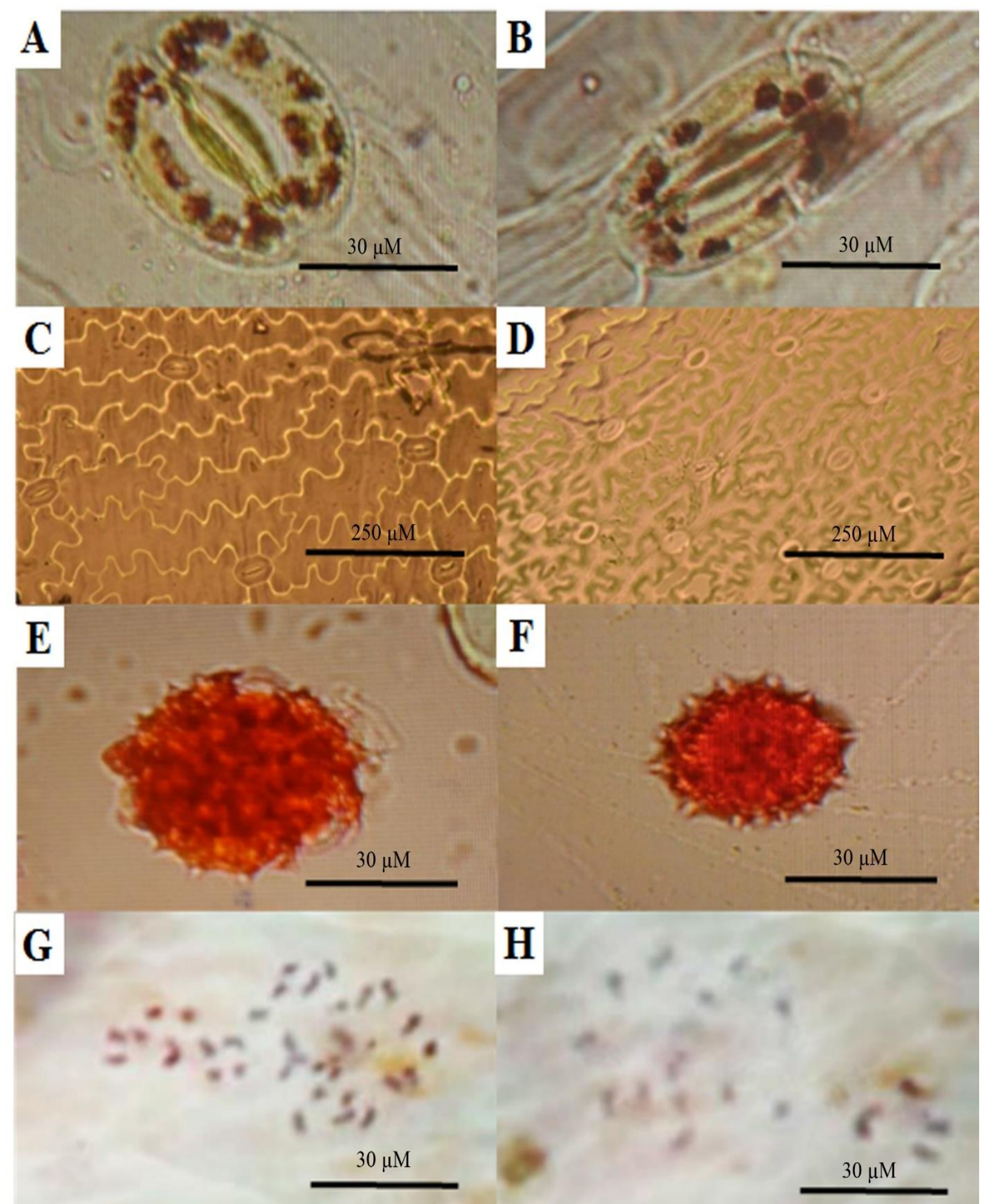

Fig. 1. Comparison of various traits of tetraploid and diploid chamomile. Chloroplast number (A) and stomatal density (C) in tetraploid and diploid (B and D, respectively). Mature chamomile pollen grains (400x) of treated chamomile (E) and control (F). Number of chromosomes in tetraploid (G) and diploid (H) chamomile (1000x). 
Table 5. b-chlorophyll content in different chamomile cultivars treated with different concentrations of trifluralin

\begin{tabular}{|c|c|c|c|}
\hline \multirow{2}{*}{ Cultivar } & Concentration $(\mu \mathrm{M})$ & \multicolumn{2}{|c|}{ b-chlorophyll $\left(\mathrm{mg} \cdot \mathrm{g}^{-1}\right)$} \\
\cline { 2 - 4 } & & Seeds application & Apical buds application \\
\hline \multirow{3}{*}{ Bona } & 0 & $2.22^{\mathrm{g}}$ & $2.23^{\mathrm{f}}$ \\
\cline { 2 - 4 } & 7.5 & $2.97^{\mathrm{f}}$ & $3.17^{\mathrm{d}}$ \\
\cline { 2 - 4 } & 15 & $3.45^{\mathrm{d}}$ & $3.72^{\mathrm{c}}$ \\
\cline { 2 - 4 } & 22.5 & $3.90^{\mathrm{b}}$ & $2.50^{\mathrm{a}}$ \\
\hline \multirow{3}{*}{ Dehroud-e-Dashtestan } & 0 & $2.28^{\mathrm{g}}$ & $3.50^{\mathrm{e}}$ \\
\cline { 2 - 4 } & 7.5 & $3.28^{\mathrm{e}}$ & $3.90^{\mathrm{b}}$ \\
\cline { 2 - 4 } & 15 & $3.68^{\mathrm{c}}$ & $4.58^{\mathrm{a}}$ \\
\cline { 2 - 4 }
\end{tabular}

a reduction in the internode length accompanied by an increase in the number of buds formed per unit area is responsible for the observed increase in the number of lateral branches in the tetraploid plants.

According to Masterson (1994) the volume and membrane surface of tetraploid cells are, respectively, about 2 and 1.5 times larger than their diploid counterparts resulting in an overall larger plant size. Polyploidy induction increases the size and thickness of leaves by increasing the cell size. Our results on chamomile also revealed such changes, a finding that has previously been reported in other species including narrow-leaved tea-tree (Melaleuca alternifolia (Maiden \& Betche) Cheel) (Zhang et al., 2000), basil (Ocimum basilicum ) (Omidbaigi et al., 2012) and Mentha mozaffarianii Jamzad (Ghani et al., 2014). In addition to leaf structure alteration, trifluralin-induced tetraploid chamomile showed an increase in flower and receptacle diameter and a decrease in the number of flowers in tetraploid plants. Such changes have also been reported by others including those of Raev et al. (1996) in Lavender.

In polyploid plants the photosynthetic rate is correlated with the amount of DNA per cell (Warner \& Edwards, 1993), while photosynthetic rate is related to the number of photosynthetic cells per unit leaf area (Vyas et al., 2007). Such changes in cell surface area and volume appear to be an advantage for the metabolic activity of polyploids (Lavania \& Srivastava, 1991). An increase in chlorophyll content, as detected here in trifluralininduced tetraploid chamomile, is in line with such changes. It has been reported that trifluralin in a concentration and incubation time-dependent manner caused an increase in leaf chlorophyll content (Amiri et al., 2010).

As expected, an increase in both the duration of application and concentration of trifluralin resulted in a reduction in stomatal density, accompanied with an increase in chloroplast number in stomatal guard cells and stomatal width and length. As shown previously, increased cell size due to polyploidy can increase stomatal size while decreasing stomatal density (Masterson, 1994). Later, Roy et al. (2001) reported the mean stomatal length and width of 27.8 and $24.3 \mu \mathrm{m}$, respectively, in diploid Humulus lupulus L., values smaller than those of the tetraploid (length: 43.5 , width: $33.3 \mu \mathrm{m}$ ). Sahrkhiz (2007) also showed that polyploidy induction could increase the stomata size in Tanacetum parthenium. Similar results were also reported in Ocimum basilicum (Omidbaigi et al., 2012). Other reports on an increase in the number of chloroplasts include those in tetraploid Solanum bulbocastanum Dunal. (Hermsen \& Deboer, 1971), Ocimum basilicum (Omidbaigi et al., 2012) and Dracocephalum moldavica L.(Omidbaigi et al., 2010).

Our results on pollen grains revealed a larger pollen grain in tetraploids, a finding also reported by Seidler-Lozykowska (2003), where a 25\% increase in pollen diameter had been detected. The chromosome count made in root apical cells was performed in order to show the ploidy level in trifluralin-treated chamomile. As expected, our observations indicated the chromosome numbers in somatic cells of 18 and 36 in diploid and tetraploid chamomile, respectively. In addition, our results revealed a trifluralin concentration-dependent induction of polyploidy in chamomile. In Fenugreek (Trigonella foenum-graecum L.) the application of trifluralin in $22.5 \mu \mathrm{M}$ concentration at $24 \mathrm{~h}$ had the most ploidy induction and the karyotypes of chromosomes changed (Afshari et al., 2009). a finding also reported in Tanacetum parthenium (Saharkhiz, 2007), Mentha mozaffarianii (Ghani et al., 2014), Catharanthus roseus (Hoseini et al., 2012), Dracocephalum moldavica (Omidbaigi et al., 2010), Ocimum basilicum (Omidbaigi et al., 2012) and Carum carvi L. (Dijkstra \& Speckmann, 1980).

\section{CONCLUSION}

Based on our results, it can be concluded that trifluralin at the highest concentration used in this study (ie., $22.5 \mu \mathrm{M}$ ) causes significant changes in both Bona and Dehroud-e-Dashtestan cultivars of 
chamomile. Due to the significant differences in several characteristics such as chromosome number, stomatal size and density between diploid and tetraploid chamomile, these qualities could be considered as suitable criteria for the detection of tetraploid plants.

\section{ACKNOWLEDGEMENT}

We would like to thank the head of the Agriculture and Natural Resources Faculty of the Persian Gulf University and the Biotechnology Laboratory for their support.

\section{REFERENCES}

Afshari, E., Ranjbar, G.A., Kazemitabar, S.K., Riasat, M. and Kazemi Poshtmasari, H. 2009. Effect of trifluralin herbicide on polyploidy induction and chromosome changes in root meristem cells of fenugreek (Trigonella foenum-graecum L.). - J. Crop Breed. 2: 69-86.

Amiri, S., Kazemitabaar, S.K., Ranjbar, G. and Azadbakht, M. 2010. The effect of trifluralin and colchicine treatments on morphological characteristics of Jimsnoweed (Datura stramonium L.). - Trakia J. Sci. 8: 47-61.

Bartels, P.G. and Hilton, J.L. 1973 Comparison of trifluralin, oryzalin, pronamide, propham, and colchicine treatments on microtubules. - Pestic. Biochem. Physiol. 3: 462-472.

Bhaskaran, N., Shukla, S., Srivastava, J.K. and Gupta, S. 2010. Chamomile: an anti-inflammatory agent inhibits inducible nitric oxide synthase expression by blocking RelA/p65 activity. - Int. J. Mol. Med. 26: 935-940.

Bijak, M., Saluk, J., Tsirigotis-Maniecka, M., Komorowska, H., Wachowicz, B., Zaczyńska, E., ... and Pawlaczyk, I.. 2013. The influence of conjugates isolated from Matricaria chamomilla L. on platelets activity and cytotoxicity. - Int. J. Biol. Macromol. 61: 218-229.

da Silva, G.M., Varella, T.L., Karsburg, I..V., Santana, T.N., de Carvalho, I.F., da Silva Añez, R. B., and da Silva, M.L. 2017. Cytogenetic characterization of species and hybrids of orchids of Cattleya genus. Cytologia 82: 137-140.

Das, M. 2014. Chamomile: medicinal, biochemical, and agricultural aspects. - CRC Press, New york. 295 pp.

Dhawan, O. and Lavania, U. 1996. Enhancing the productivity of secondary metabolites via induced polyploidy: a review. - Euphytica 87: 81-89.

Dijkstra, H. and Speckmann, G. 1980. Autotetraploidy in caraway (Carum carvi L.) for the increase of the aetheric oil content of the seed. - Euphytica 29: 8996.

Ghani, A., Neamati, S.H., Azizi, M., Saharkhiz, M.J. and Farsi, M. 2014. Artificial autotetraploidy induction possibility of two Iranian endemic mint. - Not. Sci. Biol. 6: 185.

Hermsen, J.T. and De Boer, A. 1971. The effect of colchicine treatment on Solanum acaule and $S$. bulbocastanum; a complete analysis of ploidy chimeras in S. bulbocastanum. - Euphytica 20: 171180.

Hoseini, H., Chehrazi, M., Nabati Ahmadi, D. and Mahmoudi Sarvestani, M. 2012. Ploidy induction in rosy periwinkle (Catharanthus roseus) and phenotype alteration (in Persian). Presented at the $1^{\text {st }}$ National Conference on Solutions to Access Sustainable Development in Agriculture, Natural Resources and the Environment. Tehran, Iran.

Lavania, U. 2005. Genomic and ploidy manipulation for enhanced production of phyto-pharmaceuticals. Plant Genet. Resour. 3: 170-177.

Lavania, U. and Srivastava, S. 1991. Enhanced productivity of tropane alkaloids and fertility in artificial autotetraploids of Hyoscyamus niger L. Euphytica 52: 73-77.

Masterson, J. 1994. Stomatal size in fossil plants: evidence for polyploidy in majority of angiosperms. Science 264: 421-423.

Omidbaigi, R., Mirzaee, M., Hassani, M. and Sedghi Moghadam, M. 2012. Induction and identification of polyploidy in basil (Ocimum basilicum L.) medicinal plant by colchicine treatment. - Int. J. Plant Prod. 4: 87-98.

Omidbaigi, R., Yavari, S., Hassani, M.E. and Yavari, S. 2010. Induction of autotetraploidy in dragonhead (Dracocephalum moldavica L.) by colchicine treatment. - J. Fruit Ornam. Plant Res. 18: 23-35.

Raev, R., Jordanov, R. and Zheljazkov, V. 1996. Induced polyploidy in lavender. - Acta Hortic. 426: 561-572.

Roy, A., Leggett, G. and Koutoulis, A. 2001. In vitro tetraploid induction and generation of tetraploids from mixoploids in hop (Humulus lupulus L.). - Plant Cell Rep. 20: 489-495.

Rubuluza, T., Nikolova, R., Smith, M. and Hannweg, K. 2007. In vitro induction of tetraploids in Colophospermum mopane by colchicine. - S. Africa J. Bot. 73: 259-261.

Saharkhiz, M. 2007. The effects of some environmental factors and ploidy level on morphological and physiological characteristics of feverfew (Tanacetum parthenium L.) medicinal ornamental plant. Ph.D thesis, Tarbiat Modares University, Tehran. Iran.

Salma, U., Kundu, S. and Mandal, N. 2017. Artificial polyploidy in medicinal plants: Advancement in the last two decades and impending prospects. J. Crop Sci. Biotechnol. 20: 9-19.

Sattler, M.C., Carvalho, C.R. and Clarindo, W.R. 2016. The polyploidy and its key role in plant breeding. Planta 243: 281-296.

Seidler-Lozykowska, K. 2003. Determination of the ploidy level in chamomile (Chamomilla recutita (L.) Rausch.) strains rich in $\alpha$-bisabolol. - J. Appl. Gent. 44: 151-155.

Singh, O., Khanam, Z., Misra, N. and Srivastava, M.K. 2011. Chamomile (Matricaria chamomilla L.): An overview. - Pharmacogn Rev. 5: 82-95.

Srivastava, J.K., Shankar, E. and Gupta, S. 2010. Chamomile: A herbal medicine of the past with bright future. - Mol. Med. Rep. 3: 895-901. 
Tayel, A.A. and El-Tras, W.F. 2009. Possibility of fighting food borne bacteria by egyptian folk medicinal herbs and spices extracts. - J. Egypt Public Health Assoc. 84: 21-32.

te Beest, M., Le Roux, J.J., Richardson, D.M., Brysting, A.K. and Suda, J., Kubešová, M. and Pyšek, P. 2012. The more the better? The role of polyploidy in facilitating plant invasions. - Ann. Bot. 109: 19-45.

Vyas, P., Bisht, M.S., Miyazawa, S-I., Yano, S. and Noguchi, K., Terashima, I.and Funayama-Noguchi, $S$. 2007. Effects of polyploidy on photosynthetic properties and anatomy in leaves of Phlox drummondii. - Funct. Plant Biol. 34: 673-682.

Warner, D.A. and Edwards, G.E. 1993. Effects of polyploidy on photosynthesis. - Photosyn. Res. 35: 135-147.

Wendel, J.F. 2015. The wondrous cycles of polyploidy in plants. - Am. J. Bot. 102: 1753-1756.

Zhang, X., Liang, G., Yan, Y., Yu, Y., Yang, G. and Yang, T. 2000. Rapid propagation and polyploidy induction in Melaleuca alternifolia. - J. Southwest Agricul. Univ. 22:507-509.

How to cite this article:

Karami, L., Modarresi, M., Kohanmoo, M.A., Zahabi Ahmadi, F. and Irian, S. 2019. Polyploidy induction in German chamomile (Matricaria chamomilla L.) by herbicide Trifluralin. - Nova Biol. Reperta 6: 311-319. 